\title{
OCCURRENCE OF LEGIONELLA SPP. IN SELECTED PUBLIC FACILITIES IN POLAND IN 2009-2013 AND 2014-2016: A COMPARATIVE STUDY
}

\section{WYSTĘPOWANIE BAKTERII LEGIONELLA SPP. W WYBRANYCH OBIEKTACH UŻYTECZNOŚCI PUBLICZNEJ W POLSCE W LATACH 2009-2013 ORAZ 2014-2016: ANALIZA PORÓWNAWCZA}

\author{
Jan Kazimierz Karczewski ${ }^{1(A, D, E, F)}$ \\ ${ }^{1}$ Pope John Paul II State School of Higher Education in Biała Podlaska, Poland
}

Authors' contribution Wkład autorów: A. Study design/planning zaplanowanie badań B. Data collection/entry zebranie danych C. Data analysis/statistics dane - analiza i statystyki D. Data interpretation interpretacja danych E. Preparation of manuscript przygotowanie artykułu F. Literature analysis/search wyszukiwanie i analiza literatury G. Funds collection zebranie funduszy

Tables: 1

Figures: 1

References: 22

Submitted: 2020 Apr 4

Accepted: 2020 Apr 20

\section{Summary}

Background. This paper evaluated Legionella spp. water system contamination in the public facilities.

Material and methods. Samples of warm water from the inner water supply system of 41 facilities in years 2009-2013 and 46 facilities in years 2014-2016 were collected for analyses. The facilities included school dormitories, boarding houses, school-education centers, halls of residence, nursery schools, kindergartens, and correctional institutions.

Results. The results of research carried out on tap water in public facilities in 2014-2016 showed that in comparison to 2009-2013 the percentage of facilities from group I increased. In group III facilities a decreasing tendency was observed in comparison to research carried out in 2009-2013.

Conclusions. The results indicate that it cannot be explicitly ascertained that the eradication methods of L. pneumophila from tap water systems of the analyzed facilities within the studied period were sufficient. Epidemiological analyses of this type should be successively and systematically continued and based of the largest possible number of facilities.

Keywords: Legionella pneumophila, Legionnaire disease, environmental surveillance

\section{Streszczenie}

Wprowadzenie. Celem pracy była ocena skażenia systemów wodnych $\mathrm{w}$ budynkach użyteczności publicznej przez bakterie Legionella spp.

Materiał i metody. Materiałem były próbki wody ciepłej pobrane z wewnętrznej instalacji wodociągowej 41 obiektów w latach 2009-2013 oraz 46 obiektów w latach 2014-2016. Były to: bursy szkolne, internaty, ośrodki szkolno-wychowawcze, domy studenta, żłobki, przedszkola, zakłady karne.

Wyniki. Wyniki badań sieci wody użytkowej obiektów użyteczności publicznej w latach 2014-2016 w porównaniu do lat 2009-2013, wykazały, że odsetek obiektów z grupy I wzrósł. W obiektach z grupy III stwierdzono tendencję spadkową w porównaniu do lat 2009-2013.

Wnioski. Wyniki badań świadczą, że w analizowanym okresie nie można jednoznacznie stwierdzić czy stosowane metody eradykacji L. pneumophila z systemów wody użytkowej analizowanych obiektów są wystarczające. Tego typu analizy epidemiologiczne należałoby sukcesywnie i systematycznie kontynuować w oparciu o jak największą liczbę obiektów.

Słowa kluczowe: Legionella pneumophila, choroba legionistów, nadzór środowiskowy

\section{Introduction}

The natural environment of Legionella type bacteria is water [1]. These bacteria appear in natural and artificial water systems, groundwater, littoral zones of seawater, thermal water, moist soil, and clay soil as well as near wastewater discharge. The optimal temperature for the development of the bacteria ranges between $20^{\circ} \mathrm{C}$ and $50^{\circ} \mathrm{C}[2]$. In the natural environment, they constitute less than $1 \%$ of the general population of bacteria and they do not pose an epidemiological threat [3].

Over 50 species and 72 serological groups of Legionella type bacteria were determined. Out of them at least 21 species may cause diseases in humans [4]. The majority of infections are caused by the Legionella pneumophila species (around 80-90\%). L. pneumophila causes 75-90\% of diseases and belongs to the first serological group

Karczewski JK. Occurrence of Legionella spp. in selected public facilities in Poland in 2009-2013 and 2014-2016: a comparative study. Health Prob Civil. 2020; 14(2): 131-135. https://doi.org/10.5114/hpc.2020.94654

Address for correspondence / Adres korespondencyjny: Jan Kazimierz Karczewski, Pope John Paul II State School of Higher Education, Sidorska 95/97, 21-500 Biała Podlaska, Poland, e-mail: j.karczewski@dydaktyka.pswbp.pl, phone: +48 83344 99 00, ORCID: Jan Kazimierz Karczewski https://orcid.org/0000-0002-7676-6761 Copyright: (C) Pope John Paul II State School of Higher Education in Biała Podlaska, Jan Kazimierz Karczewski. This is an Open Access journal, all articles are distributed under the terms of the Creative Commons Attribution-NonCommercial-ShareAlike 4.0 International (CC BY-NC-SA 4.0) License (http://creativecommons.org/ licenses/by-nc-sa/4.0/), allowing third parties to copy and redistribute the material in any medium or format and to remix, transform, and build upon the material, provided the original work is properly cited and states its license. 
(sg 1) [5]. Other species causing Legionnaires' disease are L. longbeachae, L. micdadei, L. bozemanii, L. feeleii, L. anisa, and others [4]. The infection occurs most often through the inhalation of water-air aerosol with drop diameter ranging from 2.0 to $5.0 \mu \mathrm{m}$ containing invasive forms of Legionella bacteria [6]. To date, three clinical forms of Legionnaires' disease have been characterized:

- legionellosis pneumonia (Legionnaires' disease, pulmonary form),

- Pontiac fever (Lochgoilhead fever),

- extrapulmonary form [5].

The severity of legionellosis pneumonia depends on coexisting diseases [5]. After the period of incubation (2-10 days) the following symptoms occur: cough of varying intensity, malaise, myalgia, fever up to $40^{\circ} \mathrm{C}$ and shivering [4]. Neurological symptoms (ataxia, headaches, confusion) and digestive disturbances (diarrhea, abdominal pain, nausea, vomiting) may also appear. Mortality in the case of the pulmonary form amounts at 15-20\% [7].

Pontiac fever is characterized by flu-like symptoms which include: fever, headaches, myalgia, and arthralgia. Diarrhea and vomiting are rare. Next, sore throat, cough, and rhinitis occur. The incubation period lasts from 30 to 120 hours, and most frequently is 36 hours long. The incidence rate amounts to around 80-95\% [4, 7]. The disease starts rapidly and the majority of cases do not require hospitalization [8].

The extrapulmonary form of Legionnaires' disease is rarely reported. In the course of the disease, apart from pneumonia, the following symptoms indicating Legionella bacillus infection of other organs occur: acute circulatory failure, sepsis syndrome, coagulation disorders andnephritis [4, 8].

In Poland, infectious diseases including legionellosis are reported based on the Act of prevention and combating infections and infectious diseases in humans. The entire population is sensitive to Legionella bacterial infections [9]. Smokers, people with immunodeficiency, people with coexisting diseases (diabetes, cancer, chronic respiratory diseases) belong to groups of patients with increased risk. Male gender and those over the age of 50 are risk factors [10]. People who have contact with tap water especially in the form of water-air aerosol experience risk of occupational exposure to Legionella bacteria [11].

Pontiac fever and Legionnaires' disease should be registered in Poland in accordance with the International Statistical Classification of Diseases and Medical Procedures introduced by WHO. In 2009-2013, 83 cases of legionellosis and 2 cases of Pontiac fever were reported while in 2014-2016 there were 59 cases of legionellosis and 5 cases of Pontiac fever [12-17].

According to reports published by the European Centre for Disease Prevention and Control in the corresponding periods, 22,897 cases of legionellosis were reported in 2009-2013 and 21,079 cases in 2014-2016 $[18,19]$.

The aim of this paper was to evaluate contamination of water supply networks in public facilities like dormitories, boarding houses, school-education centers, halls of residence with Legionella spp. bacillus as well as the analysis of eradication dynamics of Legionella spp. bacillus. The comparative analyses included chosen public facilities in Poland in the years 2009-2013 and 2014-2016.

\section{Material and methods}

Warm water samples for testing for Legionella spp. were collected by local staff members of 16 Voivodship Sanitary and Epidemiological Stations in Poland as a part of water quality monitoring. Water samples were collected in the period from January 2009 to December 2013 from water supply network of 41 facilities including nursery schools (7), kindergartens (6), penitentiary institutions (6), night shelters (5), halls of residence (6), orphanages (5) and boarding houses (6). In the period from January 2014 to December 2016 samples were collected from water supply networks of 46 public facilities such as nursery schools (9), kindergartens (9), penitentiary institutions (4), night shelters (10), halls of residence (4), orphanages (6) and boarding houses (4).

Warm water samples collected from the water supply network were tested in the laboratories of the Sanitary Inspections according to the norms and legal acts in force during the time of research:

1. PN-EN ISO 11731-2:2008 "Water quality - detection and quantitative marking of Legionella bacteria Part 2: The methods of membrane filtration for water with a small number of Legionella bacteria",

2. PN-IS011731, December 2002 "Water quality. Detection and marking of Legionella bacteria”,

3. PN-EN ISO19458:2007 "Water quality. Sample collection for microbiological analyses",

4. Decree of the Minister for Health of March 29, 2007, concerning the quality of water intended for human consumption (Journal Of Law, no. 61, item 417 as amended),

5. Decree of the Minister for Health of November 13, 2015, concerning the quality of water intended for human consumption (Journal of Laws, 2015, item 1989). 
Test results from two periods of time which were obtained from sanitary-epidemiological stations underwent statistical analysis. The statistical analysis was carried out in the STATISTICA 7.1 software. Pearson's Chi-square independence test was conducted with the relevance level $\mathrm{p} \leq 0.05$.

The evaluation threat posed by Legionella spp. bacteria in the studied facilities

The following arbitrary division of results was assumed [20]:

- group I - negative samples - samples in which $<100 \mathrm{CFU} / 100 \mathrm{ml}$ was found,

- group II - samples in which in the same test throughout the studied period, positive (value $>100 \mathrm{CFU} / 100$ $\mathrm{ml}$ ) and negative ( $<100 \mathrm{CFU} / 100 \mathrm{ml}$ ) were obtained alternately,

- group III - positive samples - samples in which $>100 \mathrm{CFU} / 100 \mathrm{ml}$ was reported (according to the Decree of the Minister for Health concerning the quality of water destined for human consumption valid for the period of studies).

The epidemiological analysis concerned solely the results of laboratory tests and did not include issues connected with Legionella spp. eradication.

\section{Results}

Research results showing the division into groups of facilities studied between 2009-2013 and comparatively in 2014-2016 where positive, negative as well as positive and negative samples containing Legionella spp. bacillus was detected in warm water supply system are presented in Figure 1 and Table 1. Results of tap water supply systems in public facilities in years 2009-2013 in comparison to years 2014-2016 show that the proportion of facilities qualified to group I increased from 40.23\% in years $2009-2013$ to $93.13 \%$ in 2014-2016. The proportion of facilities qualified to group II in the analyzed years shows a decreasing tendency from 52.46\% in 2009-2013 to $6.60 \%$ in $2014-2016$. In turn, the facilities qualified to group II in the analyzed years show a decreasing tendency from 7.31\% in 2009-2013 to 0\% in 2014-2016 (Figure 1). These data indicate that it cannot be explicitly ascertained that eradication methods of $L$. pneumophila from tap water systems of the analyzed facilities within the studied period are sufficient.

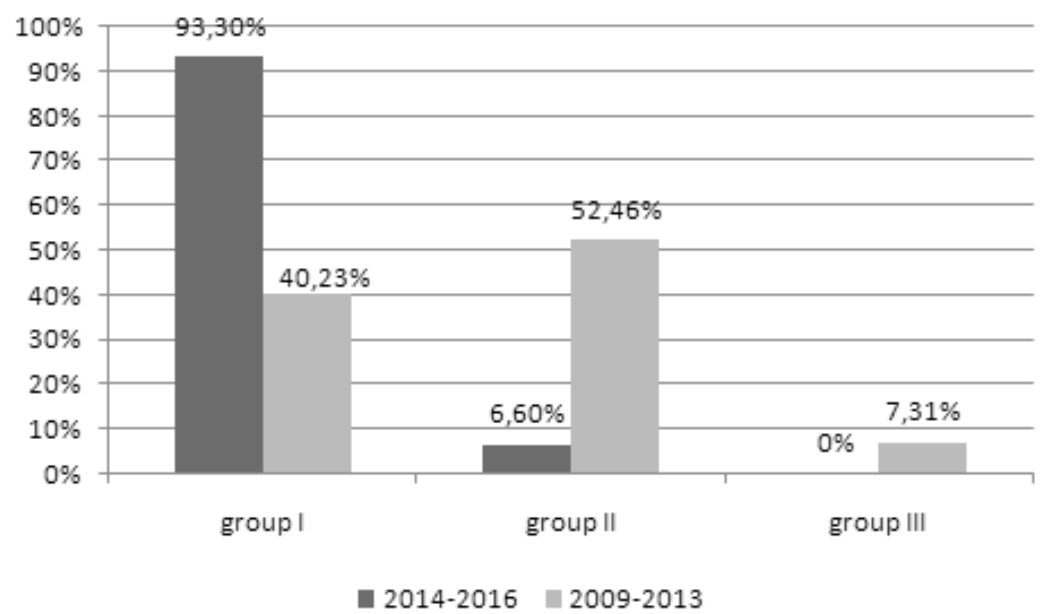

Figure 1. Evaluation threat posed by Legionella spp. bacteria in studied public facilities in years 2009-2013 in comparison to years 2014-2016

The mean number of colonies of Legionella spp. in the water samples studied in 2014-2016 was distinctly higher in comparison to 2009-2013, however the difference was not statistically significant (Table 1).

Table 1. The number of Legionella spp. colonies in years 2009-2013 and 2014-2016

\begin{tabular}{|c|c|c|c|c|c|}
\hline no. & $\begin{array}{c}\text { Year of sample } \\
\text { collection }\end{array}$ & $\begin{array}{c}\text { Number of } \\
\text { facilities }\end{array}$ & $\begin{array}{c}\text { Mean number of } \\
\text { colonies } \overline{\boldsymbol{x}}\end{array}$ & $\begin{array}{c}\text { Standard deviation } \\
\mathbf{\pm} \text { SD }\end{array}$ & $\begin{array}{c}\text { Standard error } \\
\text { SE }\end{array}$ \\
\hline 1 & $2009-2013$ & 41 & 223.33 & 589.74 & 60.51 \\
\hline 2 & $2014-2016$ & 46 & 485.00 & 1518.09 & 216.87 \\
\hline
\end{tabular}

Notes: $1-2$ : $\mathrm{Z}=1.52 ; \mathrm{p}=0.1274$

Relations between the years 2009-2013 and 2014-2016. 


\section{Discussion}

The obligation of supervision over the quality of water destined for human consumption in public facilities in which smaller or larger groups of people reside is enforced by a Decree of the Minister for Health. On January 11, 2018, an amended Decree of the Minister for Health of December 7, 2017, concerning the quality of water intended for human consumption became effective (Journal of Laws, 2017, item 2294). The changes pertain among others the obligation to conduct tests of warm water for the presence of Legionella spp. bacteria. According to the current regulations, such tests should also be carried out in public facilities where water-air aerosol is produced during utilization [21].

The analyzed group of public facilities such as dormitories, boarding houses, school-education centers, halls of residence, nursery schools, kindergartens, penitentiary institutions has been underfunded for many years. Lack of renovations including water supply systems contributed to the colonization of Legionella bacillus. The analyses of research carried out in two periods show that the epidemiological situation is improving but not to a satisfactory extent.

Research conducted in 111 public facilities in the Małopolska region in 2016 shows the colonization of Legionella bacillus in $43.2 \%$ of analyzed facilities such as primary schools, secondary schools, post-secondary schools, dormitories, boarding houses, halls of residence and school-education centers [21]. Research carried out in the years 2009-2013 shows a very high level of contamination with Legionella bacteria in the water supply system of buildings. It is connected with the underfunding of such institutions [7]. The results obtained in the comparative period may be a positive trend. Similar research was conducted by Italian authors in orphanages and retirement homes demonstrating the colonization by Legionella bacillus in $36.8 \%$ of the collected samples [22].

In the available databases, there were not enough published papers concerning the evaluation of threat in dormitories, boarding houses, school-education centers, and halls of residence to compare obtained results with the results by other authors.

\section{Conclusions}

1. The results of the research indicate that it cannot be explicitly ascertained that eradication methods of L. pneumophila from tap water systems of the analyzed facilities within the studied period are sufficient.

2. Epidemiological analyses of this type should be successively and systematically continued on the bases of the largest possible number of facilities.

\section{Disclosures and acknowledgements}

The author would like to thank:

- Voivodship Sanitary Inspectors for sharing test results;

- Iwona Gładysz, PhD, Agnieszka Sikora, PhD, and Małgorzata Wójtowicz-Bobin, PhD, for their valuable help as well as substantive and editorial guidelines which highly contributed to the article.

\section{References:}

1. Gordon M, Jahnz-Różyk K, Pancer K. [Current legionellosis diagnostics]. Forum Zakażeń. 2013; 4(2): 119-126 (in Polish).

2. Pancer K, Stypułkowska-Misiurewicz H. [Pontiac fever - non-pneumonic legionellosis]. Przegl Epidemiol. 2003; 57(4): 607-612 (in Polish).

3. Felice A, Franchi M, De Martin S, Vitacolonna N, Iacumin L, Civilini M. Environmental surveillance and spatiotemporal analysis of Legionella spp. in a region of northeastern Italy (2002-2017). PLoS ONE. 2019; 14(7): e0218687. https://doi.org/10.1371/journal.pone.0218687

4. Maziarka D, Matuszewska R, Krogulska B. [Health risks related to the occurrence of Legionella spp. in water supply systems of healthcare institutions. Interpretation of the water research results and overview of the recommendations and regulations in selected countries]. Warszawa: Narodowy Instytut Zdrowia Publicznego - Państwowy Zakład Higieny; 2016. p. 3-4 (in Polish).

5. Pancer K, Stypułkowska-Misiurewicz H. [Epidemiology of cases cased by Legionella spp.]. Nowa Med. 2009; 1: 61-65 (in Polish).

6. Sikora A, Wójtowicz-Bobin M, Kozioł-Montewka M, Magryś A, Gładysz I. Prevalence of Legionella pneumophila in water distribution systems in hospitals and public buildings of the Lublin region of eastern Poland. Ann. Agric. Environ. Med. 2015; 22(2): 195-201. https://doi.org/10.5604/12321966.1152064 
7. Shpakou A, Gładysz I, Sikora A, Wójtowicz-Bobin M, Kozioł-Montewka M. Legionella spp. in selected public utility buildings in Poland in 2009-2013. Health Prob Civil. 2017; 11(2): 117-123.

https://doi.org/10.5114/hpc.2017.69031

8. Elikowski W, Małek-Elikowska M, Ganowicz-Kaatz T, Fertała N, Zawodna M, Pyda M. Asymptomatic cardiac and gallbladder involvement at initial presentation of Legionnaires' disease. Pol Merkur Lekarski. 2020; 48(283): 60-64.

9. Krogulska B, Matuszewska R, Krogulski A, Szczotko M, Bartosik M, Maziarka D, etal. [Occurrence of Legionella in technological water and studies of the total number of bacteria and fungi in indoor air at workplaces where water aerosol is generated]. Med Pr. 2014; 65(3): 325-334 (in Polish). https://doi.org/10.13075/mp.5893.2014.040

10. Stypułkowska-Misiurewicz H, Czerwiński M. [Legionellosis in Poland in 2017]. Przegl. Epidemiol. 2019; 73(2): 151-155 (in Polish).

11. Krogulska B, Matuszewska R, Bartosik M, Krogulski A, Szczotko M, Maziarka D. [Respiratory symptoms among industrial workers exposed to water aerosol. A pilot study of process water and air microbial quality]. Med Pr. 2013; 64(1): 47-55 (in Polish). https://doi.org/10.13075/mp.5893/2013/0006

12. Czarkowski MP, Cielebąk E, Kondej B, Staszewska E. [Infectious diseases and poisonings in Poland in 2009 ]. Warszawa: National Institute of Public Health - National Institute of Hygiene - Department of Epidemiology; 2010. p. 47 (in Polish).

13. Czarkowski MP, Cielebąk E, Kondej B, Staszewska E. [Infectious diseases and poisonings in Poland in 2010]. Warszawa: National Institute of Public Health - National Institute of Hygiene - Department of Epidemiology; 2011. p. 48 (in Polish).

14. Czarkowski MP, Cielebąk E, Kondej B, Staszewska E. [Infectious diseases and poisonings in Poland in 2011]. Warszawa: National Institute of Public Health - National Institute of Hygiene - Department of Epidemiology; 2012. p. 48 (in Polish).

15. Czarkowski MP, Cielebąk E, Kondej B, Staszewska E. [Infectious diseases and poisonings in Poland in 2012]. Warszawa: National Institute of Public Health - National Institute of Hygiene - Department of Epidemiology; 2013. p. 48 (in Polish).

16. Czarkowski MP, Cielebąk E, Kondej B, Staszewska E. [Infectious diseases and poisonings in Poland in 2013]. Warszawa: National Institute of Public Health - National Institute of Hygiene - Department of Epidemiology; 2014. p. 48 (in Polish).

17. Czarkowski MP, Cielebąk E, Staszewska-Jakubik E, Kondej B. [Infectious diseases and poisonings in Poland in 2016]. Warszawa: National Institute of Public Health - National Institute of Hygiene - Department of Epidemiology; 2017. p. 57 (in Polish)

18. European Centre for Disease Prevention and Control. Legionnaires' disease. Annual epidemiological report for 2017 [Internet]. Stockholm: ECDC; 2019 [cited 2020 Apr 18]. Available from: https://www.ecdc.europa. eu/sites/default/files/documents/AER_for_2017-Legionnaires-disease_1.pdf

19. European Centre for Disease Prevention and Control. Annual epidemiological report 2014 - Legionnaires' disease [Internet]. ECDC; 2015 [cited 2020 Apr 18]. Available from: https://www.ecdc.europa.eu/sites/default/files/documents/Legionnaires\%E2\%80\%99\%20disease\%20AER_0.pdf

20. Gładysz I, Kozioł-Montewka M, Sikora A, Wójtowicz-Bobin M, Karczewski J. Prevalence of Legionella spp. in hot water samples from Polish hospitals in 2009-2013. Postepy Hig. Med. Dośw. 2019; 73: 47-52. https://doi.org/10.5604/01.3001.0013.0172

21. Żak J, Orlińska K, Koperny M, Foremny J, Bandoła K, Bała M. Legionella spp. in water systems in public teaching and education facilities in małopolskie voivodeship in 2016. Przegl Epidemiol. 2019; 73(2): $227-237$. https://doi.org/10.32394/pe.73.21

22. De Filippis P, Mozzetti C, Messina A, D’Alò GL. Prevalence of Legionella in retirement homes and group homes water distribution systems. Total Environ. 2018; 643: 715-724.

https://doi.org/10.1016/j.scitotenv.2018.06.216 